\title{
'Though he slay me, yet will I trust in him': a critical reconstruction of Winnicott's theory of value
}

\begin{abstract}
This paper extrapolates an outline for a theory of value from Winnicott's reflections on war in 'Discussion of war aims' (1940). The author treats Winnicott's discussion as an occasion for a critical reconstruction of his theory of life-values. He discerns an implicit set of distinctions in Winnicott's reflections on war, including, different orders of value (existential, ethical, and psychosocial); a distinction between maturity and necessity; and a yet more fundamental distinction between violence and brutality. The paper argues, on the basis of these distinctions, that Winnicott allows for an understanding of one's encounter with the enemy as an ethical relation. The main argument of the paper is that the ethical attitude underpins recognition of the enemy's humanity. On a more critical note, the author argues that Winnicott doesn't adhere consistently to the ethical attitude he presupposes, that in certain passages he privileges the maturity of combatants over the humanity of the enemy.
\end{abstract}

Keywords: donation of goodness; enemy; life-values; survival; use-value; violence; war; Winnicott

War provides an occasion for psychoanalytic thinking. A catalyst at various points in Freud's work (1915; 1933), war certainly played a part in the formulation of the final drive theory (1920), including, the emphasis on the compulsion to repeat and the introduction of the so-called death or destructive drives. But this is a two-way street, insofar as psychoanalytic theories about war also form part of the discourse of war. Staying with the example of Freud, his "thoughts for the times on war" may be seen as a discursive intervention in the international debate about war, amounting to a direct engagement with the war effort. The emphasis on 'intervention' is especially important in clarifying the political role of psychoanalysis in the context of war.

By privileging the hypothesis of the death drive psychoanalytic ideas about war since Freud have adopted a particular, somewhat restricted focus. The application of Freudian instinct theory to military conflict encourages a preoccupation with the 'psychotic factors' affecting war and institutional violence. Segal (1997) epitomises this approach. And yet there are ways of addressing war from a psychoanalytic perspective that do not rely on the notion of innate sadism. In an attempt to explore an analytic perspective on war that doesn't ground human striving, aggression, and destructiveness in the death drive, the following discussion is based largely on Winnicott's 'Discussion of War Aims' (1940). The paper was written ostensibly in response to war, although I shall consider the extent to which Winnicott's reflections provide an opportunity for a critical reconstruction of his theory of life-values in general.

To be clear, a systematic evaluation of various Freudian and post-Freudian perspectives on war is not my topic here. How far psychoanalysis may contribute to our understanding of war remains an open question, and I am not suggesting that Winnicott's reflections on war per se are particularly insightful. In fact, I don't think he had anything more or less illuminating to say about war itself than either Freud or Klein. The important point for me is that Winnicott articulated a psychoanalytic attitude to war in which the spontaneous violence of life is prioritized over the death instinct as a primary source of aggression. And I take it that the emphasis on ruthless living in early life, rather than destructive attacks directed towards oneself (primary masochism) or 
others, has important implications for our understanding of the most basic human values. Thus the decisive shift implicit in Winnicott's discussion of war aims - a shift from the power to hurt and damage one's early internal objects to the inherently violent nature of life itself - offers important and original insights into the question of human value.

It is worth noting straightaway that Winnicott himself didn't necessarily draw out the psycho-ethical implications of his argument. Nevertheless, viewed in conjunction with his account of primitive emotional development and pre-primitive states, it seems to me that his reflections on war provide us with an outline for a theory of value.

Essentially, my argument is that Winnicott's reflection on war articulated what makes life valuable for us and, moreover, how values rather than rights or norms underpin forms of life. I shall present this argument in terms of two overarching distinctions, concerning violence and brutality on the one hand and, on the other, maturity and necessity. The former relates to the basic existential values of survival, aliveness, feeling real, and the innate reach of spontaneity; the latter, to the more mature or maturing values of goodness, concern, justice, freedom, and truthfulness. Winnicott's theory of value differs from Freud's on both counts, particularly with respect to one's sense of reality. While an advance to maturity is implicit in the Freudian interpretation, nonetheless, the discipline of necessity (Ananke) explicitly underwrites the 'reality principle' in Freud's late works (Ricoeur, 1970). By contrast, Winnicott made available a psychoanalytic model of human nature based on the complementary notions of primary creativity and emotional maturity.

Together, the criteria of creativity and maturity offer a comprehensive picture of fundamental and secondary human values, respectively. But let me say why I think we need to reconstruct Winnicott's theory of value. As a paediatrician as well as an analyst, Winnicott was a pragmatic thinker not much given to theoretical abstraction, and while the principles of creativity and maturity are presented as universal principles of human nature, they invariably operate as such within particular contexts. His reflections on war thus provide a context or an occasion from within which the general theory of value emerges, together with the crucial differentiations between violence and brutality, and maturity and necessity. Again, the important point is that Winnicott employed maturity as a criterion of health in conjunction with an understanding of violence as a spontaneous gesture of life. Nevertheless, one has to draw out the general point from the particular situation. This requires a work of critical reconstruction intent on extrapolating the general argument, while at the same time avoiding reductive generalization.

Based on Winnicott's reflections on war, then, I aim to reconstruct a theory of value rather than a programme of ethics. The reconstruction rests on two basic lines of argument: firstly, Winnicott appropriated the sociological thematic of the Freudian interpretation under the heading of 'the social provision'. The latter may be seen as a form of practical management as well as a permanent task. For example, in his last public lecture, the David Wills Lecture given in 1970 to the Association of Workers for Maladjusted Children, Winnicott (1970b, p. 228) reiterated the importance of the social provision in residential care. Most importantly, based on his wartime experience, he emphasized the primacy of survival in the face of disaster. Applied in the case of antisocial behaviour, the social provision thus becomes a permanent task of social defence. That society must be defended, and not only in times of trouble, is a basic assumption in Winnicott's psychoanalytic perspective on human values, in which the theme of survival comes increasingly to the fore.

Secondly, Winnicott retained the aggressive element in his account of the primitive love impulse, allowing for the violent and destructive aspects of the life force; while at the same time revising the Freudian conjunction of culture and civilization. 
Leaving aside the question of its intellectual credibility, Freud adhered to the concept of 'civilization' in weighing matters of social and cultural significance. By contrast, Winnicott consistently privileged culture and illusion over the civilizational perspective. In a critical-intellectual move that owes nothing to the likes of Freud, Toynbee and others, Winnicott effectively subsumed the notion of civilization and civilizational analysis under the general category of "cultural experience", which he described as "the place... where we most of the time are when we are experiencing life" (1971, p. 122). It is important not to conflate 'culture' and 'creativity' in Winnicott's evaluation of life. The idea of 'primary culture' makes no sense, insofar as one acquires a "cultural heritage" according to one's "capacity and emotional age and developmental phase" (1971, p. 129). Culture is made available in due course as cultivated experience. Nevertheless, cultural experience counts alongside primary creativity, for Winnicott at least, as among the things we "value in a special way" (1971, p. 128), and there is ruthlessness in back of creativity and culture alike.

Taking these two lines of argument as the starting point for my reconstruction of Winnicott's account of life-values, I shall argue that he allowed for the permanent underlying disposition to violence not only in the baby's experience, but also in cultural forms and more mature structures of feeling. He did so, however, without recourse to the hypothesis of the death drive and the so-called 'discontents' of civilized values. Taken together, the permanent disposition to violence and the permanent task of social defence may be seen as fundamental aspects of ordinary living. And it seems to me that Winnicott extended the critical reach of psychoanalysis as a theory of value on both counts.

\section{2}

In 'Discussion of War Aims', Winnicott sought to identify the war effort in strategic terms quite apart from any moral justification for war. As I intend to demonstrate, however, his use of the term 'strategy' reveals an underlying theory of value. The first thing to say about the emphasis on strategy is that it doesn't amount to a mere wartime propaganda exercise, but covers the more immediate concern of battle-training and field manoeuvres. Robert Graves (1929), in recounting his role as instructor, assigned to one of the Officer-Cadet Battalions in Oxfordshire during the First World War, described a focus on tactical exercises with limited objectives. Graves' account credits the Army Textbook S.S. 143, Instructions for the training of platoons for offensive action (1917), as probably "the most important War Office publication issued during the war" (1929, p. 202). The Textbook identifies the platoon rather than the company as the main tactical unit and, moreover, underwrites the military notion of strategy as a set of calculations that inform tactical manoeuvres. Strategy is defined here with an eye to risk. Winnicott's thoughts on war are consistent with this line of argument on the grounds that war is about fighting to win. This isn't necessarily an ideological argument; in fact, the same holds for Winnicott as for Graves: "A professional soldier's duty was simply to fight whomever the King ordered him to fight" (1929, p. 116). Winnicott thus endorsed Churchill's decision at the time not to discuss war aims beyond the fact that "we fight to exist" (1940, p. 210).

Ostensibly, strategic calculations rest neither on ideological motives nor on moral or political feelings about the enemy; hence Blunden's verdict, arrived at in accordance with the inward journey of the veteran, that "the war must be attended to" (1928, p. 4). We fight to exist because that is how it is. For Winnicott, as for Blunden, 
the war's purpose isn't the important motivating factor when it comes to fighting for one's existence. Accordingly, while the strategic notion of fighting to exist has moral implications, it doesn't amount to a moral justification of war. In what sense, then, might we think of Winnicott's reflections on war as moral reflections? I think if we weigh the matter with sufficient attention, 'strategy' turns out to be more than a military calculation for Winnicott. The strategic argument isn't presented as a form of military ethics - that is, with the aim of underwriting the legitimacy of war. But although he doesn't intend to make a humanitarian case for war, or for the right to make war (jus ad bellum); in effect, his reflections on war pose the question of what is due to a human being qua human being.

My attempt to reconstruct Winnicott's theory of value is based first and foremost on the use of the term and concept 'humanity' in the context of war. This comes to the fore in an estimation of the 'enemy' during wartime. Winnicott employed general criteria not as a means for justifying war on humanitarian grounds; nor yet for assuming authority to overcome the enemy; but rather, in order to credit the humanity of the enemy. His revaluation of the value of war implies universal jurisdiction in the Kantian sense, where the onus falls on one's responsibility for the enemy rather than the humanitarian motivation of the state. In particular, Winnicott viewed strategy in terms of the basic human value of survival - that is to say, over above any attempt to justify war on moral or political grounds. There is an important evaluative distinction operating here. The positive evaluation concerns the irreducible singularity of the enemy's 'humanity'; whereas the critical evaluation rests on the 'immaturity' rather than the 'inhumanity' of the enemy, an evaluation which crucially avoids the notion of the 'unjust enemy' (iniustus hostis).

Recourse to the humanity of one's enemy doesn't amount to a military argument, it doesn't relay on the criteria of 'military humanism' or the concomitant doctrine of moral idealism. We fight to exist before the war is "officially certified to be making the world safe for democracy" (Blunden, 1928, p. 5). Crucially, one is no different in this respect to one's enemy; survival strategies come naturally and as a matter of urgency to human beings in conjunction with the ethical impulse towards life. Winnicott articulated this primordial conjunction, precisely, in term of the ruthlessness of the infant and, in an unmistakably Christian idiom, the devotedness of the mother. The implications of this account are brought sharply into focus when compared to the scandal of Tóibín's revisionist account of Calvary, which turns on the Holy Mother's avowal that "my first instinct was to flee and it was also my last instinct...to protect myself' (2012, p. 84). For Winnicott, the instinct of self-protection is manifest in the baby's spontaneous gesture of life coupled with the innate prejudice of self-sacrifice in maternal care. Thus life is manifest to begin with in the baby's simultaneous reaching and being reached.

What evidence is there to support the proposal that Winnicott combined the strategic calculation of risk with an ethical evaluation of human life predicated on the notion of survival? Are there grounds, in other words, for saying that the strategic argument presupposes a fundamental theory of human value? I think there are good grounds for making a claim in support of survival strategies. Importantly, Winnicott stated that he wasn't in any way ashamed of his commitment to the idea of fighting to win. He didn't feel he was doing anything wrong and, indeed, there is no mention here of fighting to kill: "We are doing no very extraordinary thing to fight simply because we do not wish to be exterminated or enslaved" (1940, p. 210). The wish expressed in this statement presupposes a particular theory of human nature, a theory which takes the Freud-Klein perspective on oedipal and pre-oedipal formations in new directions. Most importantly, the claim about fighting to exist presupposes the vital normativity or self- 
immanence of human existence, the theory of which was set out from the 1930s onwards along the lines of the individual-environment set-up. What hasn't been addressed in the literature, however, is the extent to which the ethical and political consequences of these claims come to the fore in terms of what is due to one's enemy.

To avoid any unnecessary confusion, I shall steer clear of the phrase 'innate morality' in discussing Winnicott's contribution to the theory of life-values. I find the phrase "innate moral code" (Winnicott, 1963b, p. 101) misleading, as the depth and type of existential feeling it refers to, including the talion fears from which the infant suffers at this fundamental level, equate neither to forms of moral life nor to codes of moral conduct. Instead of 'innate morality', I refer to the intrinsic value in living in order to specify the primary feeling of life as worthwhile, the experience of feeling oneself in the sensation of living. The latter is irreducible to the culture of value, whichever form it takes: moral, aesthetic, religious or otherwise. The critical reconstruction referred to in my title, involves changing the terms of Winnicott's argument, hopefully, in order to make the argument clearer. The intrinsic value in living, what Winnicott (1963b, p. 102) called the "fiercest morality" of early infancy, constitutes the conditions that make the various forms of moral life possible. And I think this is especially evident in the discussion of war aims, where the intrinsic value in living underpins the idea that military victory is tantamount to saving one's own skin.

On this reading, paradoxical as it may sound, aggression denotes a war of defence rather than a war of conquest. We fight to exist before we fight to kill and, moreover, we do so as a spontaneous expression of life. It is a matter of first importance in this context "that we should win a military victory and not a moral victory" (1940, p. 220). The idea that "we fight to exit" (1940, p. 210) is consistent with the perspective set out in the first phase of Winnicott's mature thought during the war years. The fundamental idea here, according to Winnicott's (1988) account of the earliest states of human existence, is that living aims at life. And it does so as a matter of ruthless striving rather than latent hatred, implacable greed and envy; hence the incontestable manifestation of the aspiration to go on being, in what we might call the reach for life.

Winnicott's most prominent exponent, in Britain at least, Abram (2013, p. 79) divides his contribution into two definitive thoughts, firstly, that babies are human beings, and secondly, that the infant-parent couple constitutes the elementary form of human existence. This leads Abram to conclude in favour of an overarching theory of the 'self' as the groundwork of Winnicott's thought. Of course she isn't alone in stressing the centrality of the 'self' in Winnicott, and yet it seems to me that 'life' is accorded ontological priority in the Winnicottian theory of human nature. Selfhood remains an achievement, a particular way of coming into one's own life (a person living in his body), and I think if we are going to credit Winnicott's fundamental clinical distinction between the 'true' and 'false' self, we need to do so on the grounds that the truth of the self is life. As distinct from the various forms of self-expression that experience subsequently makes available, spontaneity presupposes a yet more fundamental gesture, the nameless singularity of which is manifest at the beginning in a state of absolute dependence. To begin with, dependence is clearly not in control of itself. The fact that the baby is there, and in the midst of life, goes together with a state of helplessness prior to the ongoing accomplishment of the self's existence. There is no way of getting behind this helpless condition at any stage in one's life, nor does 
Winnicott suggest that we can. Rather, he allows for the idea that the self is actually what it can manage to take over from helplessness. All being well, we find a niche in the world for ourselves, according to "the individual's personal broadening of the basis of tolerance" (1963a, p. 91).

In reconstructing Winnicott's theory of value, then, I want to emphasize above all the infantile aspiration to persevere in being, coupled with the corporeality of maternal love and its ways of giving: feeding, touching, holding, clothing, and object presenting. More than the sense of selfhood, it is the sensation of being thrown into the world, the overall feeling of aliveness, that I believe constitutes "the matrix of [Winnicott's] theory" (Abram, 2013, p. 104). I don't think this is simply a question of emphasis. The distinction between self and object ('me' and 'not-me') depends on the inaugural reach for meaning in pre-primitive states. The reach for meaning is at bottom a reach for life, manifest as potentiality in the "personal contribution" that the infant makes at "the theoretical first feed" (Winnicott, 1988, p. 110). Anterior to 'me' and 'not-me', an emergent instinct tension, and not yet an illusion - as such, the baby's simultaneous reaching and being reached is a condition of object-relatedness. The matrix from which the self emerges, the reach for meaning grounds 'good' and 'bad' internal objects in a pre-original manifestation of goodness.

What is good originally is good for the soma. Scarfone (2013) helps to clarify matters for us by differentiating the primordial mind and its link to the somatic substratum from the psychical field or psychic side of the mind, which comprises mental representations (fantasies) of the libidinal body. The implication being that goodness is manifest under primordial conditions prior to the imago of goodness (the good breast) in the infant's mind. Where food is given in a way for the baby to find, at the same time the donation of goodness affirms the meaning and value of life prior to identification with a good object. Theoretically, there is as yet no question of an object in any sense, not even the most rudimentary cognition or representation of an external or internal object; the donation is inaugural and predates the question of reality as well as the earliest sense of self.

Oliner (2012) underlines this distinction, in post-Freudian thought, between the self-sensing of affectivity (perceptibility) and the representation of perception. In Winnicottian terms, illusion may follow from the donation of goodness, just as faith may take hold on the grounds of love. And yet for the moment life is weighed in the anxiety of beginning and the beginning of anxiety. Thus, in what Winnicott made of the preoriginal, pre-primitive state of helplessness (Hilflosigkeit) that defines the human situation at its most fundamental, the reach or grasp for meaning is exposed to what he called 'unthinkable anxiety'. Primary creativity itself, the very potentiality of life, may be seen as a gesture of vulnerable living, where love is good above all in its responsiveness to the want of being, a love that offers itself for use. Thus Anne Enright (2015, p. 296) brings home Winnicott's point that love comes to helplessness, absorbed and without fixed limits, in infantile and adult living alike.

The donation of goodness lies at the heart of Winnicott's theory of value. As such, the gift of the theoretical first feed inaugurates a pattern of intimate contact, a way of living together, in which violence is a source of growth on the infant's part rather than the negative value of an instinctual dualism. But how are violence and the gift knotted together? The question of violence pertains directly to the reconstruction of Winnicottian 
life-values and, in the context of war, brings the difficult relationship between existential values, ethics, and the law sharply into focus.

The first thing to say is that unless she values violence as an activity in itself, the mother isn't in a sufficiently sensitive position to credit the infant's contribution at the beginning, or to adequately accommodate her baby's capacity for love. Far from divesting love of violence, maternity accommodates violence in love. Babies make a claim on the goodness of the world in violent ways, starting with the claims they make on the mother's body, or what Winnicott called the 'environment-mother'. And to the extent that the mother is "infinitely bothered by the infinite claims of her own children" (Winnicott, 1960, p. 74), accommodation comprises a burden of care and attentiveness. In this respect, reliability differs from containment and may be seen as a state in which the mother is held fast in holding her baby.

Winnicott was keen to point out that he was referring to real, fallible mothers, "actual people with babies", whose responding in a "sensitively good enough" way is nonetheless crucial as a condition of possibility for illusion (Rodman, 1987, p. 38). Again, the best a real woman can do in this situation comes up against a violent claim that calls out love. In a remarkable meditation on maternity in her novel Lila, Marilynne Robinson describes the child's need to "rest her head on a bosom more Doll's than Doll herself" (2014, p. 54), a need to have someone holding her that calls on everything the mother has to give and more. As such, responding and holding involve the substitution of oneself (all one's own) for the very violence of the other human being, where egocoverage supports life to the farthest excess of ruthless love. Mother and baby thus embody the intimacy of human contact in the primordial encounter of helplessness and preoccupation prior to the apperception of self and the apprehension of beauty.

Under favourable conditions we come to various mature understandings of what matters; we enjoy mature involvements; but only on the basis of what makes life worth living in the first place. What matters waits on living. In this respect, the environmentindividual set-up may be seen as both a manifestation of life and a precondition of psychological and moral values. Winnicott allows for a crucial distinction between primary and secondary orders of value, or between ethics and morality. The moral sense - what Winnicott calls 'concern' - emerges in conjunction with the sense of reality against the background of love and violence, where the mother responds to her baby as another life. As the pre-primitive complement to the infantile complex of helplessness and ruthless love, maternity embodies the response of responsibility: "here I am [me voici]" (Isa. 6.8). Distinct from moral value, the latter comprises the ethical situation par excellence.

To state my main argument, love and violence come decisively to the fore through Winnicott's estimation of the 'enemy' during wartime. While the banality of killing in warfare turns on the legitimate use of violence, nonetheless, one is answerable to something stronger than murder in the humanity of one's enemy. But what force is there in war, greater than the brute fact of killing? In a thought of some historic significance Winnicott lets us see the extent to which war doesn't represent the primordial event in the encounter with one's enemy. He confirms the fact that war is a particular historical and political context, a field of manoeuvre, within which one comes face to face with a more fundamental situation. However violent it turns out to be, war isn't the first word in the encounter with the enemy, even as survival isn't aimed at dominion over one's enemy. The calculation of risk is overdetermined by the value of survival, where the ethical meaning of survival pertains outside the regulation of violence and the use of force by the state. 
In reconstructing Winnicott's theory of value, then, it is incumbent upon us to credit the primordial expression of human goodness beyond the inculcation of the "offensive spirit" (Graves, 1929, p. 151). Winnicott augmented the meaning of strategy by identifying the strategic argument with the inextricability of goodness and survival in the fundamental human situation. Subscribing to this argument, however, doesn't afford moral superiority over the enemy. To the contrary, we fight as a matter of course, but "do not thereby claim to be better than our enemies" (1940, p. 210).

I want to suggest a somewhat unlikely comparison now between Winnicott and Jean Genet, which seems particularly relevant to me on at least two counts: first, they both address war in terms of an underlying distinction between violence and brutality. Secondly, their views on war and violence allow for the irreducible singularity of the enemy, something which is crucial for my reconstruction of Winnicottian life-values. Genet set out the basic distinction between violence and brutality in his 1978 preface to a collection of writings by members of the Red Army Faction. In the preface, which was also published as an article in Le Monde, Genet (1977, pp. 171-72) argued that life comprises innumerable examples of "necessary violence", the "spontaneity" and "uninterrupted dynamic" of which is infringed by systematic and organized acts of brutality. Genet identifies the "the spontaneous violence of life" (1977, p. 171) with the birth of a child, and also with "the kernel of wheat that germinates and breaks through the frozen earth" (1977, p171). Far from a refusal of the gift that announces and inaugurates life, violence is seen as essentially part of the ongoing process of giving birth and making anew. On the other hand, Genet returns repeatedly in interviews, speeches, and manifestos to racism and hatred of the other person, as well as the probing and intrusions of the police and the state, as forms of organized brutality.

Similarly, in 'Primitive Emotional Development', a seminal paper published at the end of the war in 1945, Winnicott postulated an early ruthless object relationship, as distinct from sadism and murderous envy. The notion of 'intrusion' plays an important part in the development of Winnicott's thinking, but unlike Klein, he didn't equate aggression at this stage of life with destructive, intrusive attacks in unconscious fantasy. Rather, the emphasis lies on the violent penetration of love. I don't know that this paper has been linked to the theme of war, and yet the link seems clear enough. The baby is described as aggressive in specific and violent ways; it hurts its mother and wears her out. But even as the baby goes at its mother in a savage way, Winnicott maintains that it isn't driven by innate hatred or any brutal intent. Like Genet, he equates the "reaching impulse" with life: "when a baby goes for the breast and drinks milk, in fantasy he puts his hands in, or dives into, or tears his way into his mother's body, according to the strength of the impulse and its ferocity, and takes from her breast whatever is good there" (1941, p. 64). The violent appropriation, for Winnicott at least, isn't driven by envy of original goodness, but remains without compromise on the side of life.

The description Winnicott gives of the reach for life recalls Klein's account of assaults on the mother's body, the infant's fantasy of penetrating mother sadistically, "with its teeth, nails and excreta and with the whole of its body" (1932, p. 130), together with the anxieties to which these "destructive cravings" and gratuitous feelings of envy give rise. I take it that besides the paediatric foundations of his thinking, Winnicott's greatest debt was to Klein, who broke the Freudian mould and set psychoanalysis on a new path in the second half of the twentieth-century. It needs repeating that Winnicott 
was essentially a post-Kleinian and, in that respect, on a par with Bion in their generation of English analysts. Nevertheless, he came to his own conclusions about cruelty and intrusion, the part they played in the earliest relationship, and in particular the conditions of possibility for a "sense of real living" (1988, p. 128) at the beginning. He didn't focus primarily on the cruelty of the internal situation, or the splitting of the ego as coextensive with an active splitting of the object. Instead, he (1988, p. 133) differentiates between violence as "inherent in the primitive love impulse" on the one hand and, on the other, "the interruption of the continuity of being" as a type of environmental brutality or impingement.

Impingement is understood as necessarily harmful and often cruel, involving the use of what Winnicott (1941, p. 54) describes in a direct echo of Genet as "brutal strength" against the infant's body, for instance, forcing something into its mouth. On the other hand, there is nothing in the least peculiar or anomalous about a proclivity towards violence that is continuous with life itself. The infant is ruthless towards the mother, "immoderate" according to Freud (1933 [1932], p. 123), precisely in terms of the demands it makes for love. And in Winnicott's (1941) attempt to simulate the fundamental human situation by the use of a spatula game in clinical consultations with mothers and babies, it appears that the exercise of brutal strength, the fact of doing harm, cuts across the spontaneous rhythm of life. The harm, in this case, consists in intruding on moments of stillness and expectancy as well as inhibiting the reaching impulse prior to any subsequent "restriction of an ego-function" (Freud, 1926, p. 89). Brutality thus breaks the thread of life that is ordinarily and immoderately forceful from the beginning.

Prior to any discussion about what counts as a legitimate use of physical force, the basic distinction between violence and brutality is evident in Winnicott and Genet alike. And in comparing their thoughts on war, the further point I wish to make is that the spontaneous gesture of violence, understood above all as a manifestation of aliveness, exposes one to an 'enemy' rather than mere 'prey'. We are faced with a human being rather than an animal to be hunted and slaughtered, and it isn't necessarily what the enemy does but who he is that occasions our faith: "Though he slay me, yet will I trust in him: but I will maintain mine own ways before him" (Job 13.15). Leaving aside the question of Satan's part in Job's suffering, the statement of faith is nonetheless grounded in the donation of goodness and the glory of God. Thus Job would still trust and hope in Him, even if God did slay him. At the same time, the avowal of "mine own ways" signifies a refusal to brutalize the enemy and, therefore, a resistance to the arbitrary use of violence in wartime. Fidelity to the humanity of one's enemy doesn't rely on moral judgements of good and evil, or psychologically derived notions of good and bad objects. As long as we fight to exist, we do not make any moral claims over and above the actions of our enemy; we do not "assert that we have some quality that our enemies lack" (1940, p. 210). And so long as Winnicott adheres to this claim, his notion of 'survival' retains its ethical meaning.

The basic assumption, here, is that everyone in a state of health fights to exist, and that one is no better or worse than anyone else in this fundamental respect.

Winnicott was not in any sense a synoptic thinker, nor did he rely on metapsychological abstraction or an all embracing dogma; nonetheless, he appealed to certain universals in attempting to articulate a coherent theory of human nature. The ahistorical and essentialist nature of his developmental theory is self-evident, and the vocabulary of 'value' seems more appropriate to me than the vocabulary of 'rights' in reconstructing his reliance on universal principles. Although he refers to a sense of entitlement in psychic life, something that the child who steals, for instance, feels he has a right to 
(1956, p. 121); he doesn't thereby invoke 'humanity' in defence of the rights of all human beings.

I don't believe that Winnicott addressed the combination of universal principles and intrinsic value in any systematic way. However, his theory of value seems consistent to me in its core conceptualization, from the late 1930s onwards. The conviction that there is something more deep-rooted in human nature than nihilism provides a coherent frame of reference across a period of 30 years or more. In particular, the idea of violence, as distinct from brutality, articulates the theoretical consistency that underlies the shift in Winnicott's conceptual vocabulary from 'aggression' to 'destruction'. Although my argument focuses on a relatively early paper from 1940, Winnicott subscribes throughout to the fundamental idea that violence is both a primary manifestation of life and a source of human growth and development.

Nevertheless, the positive evaluation of violence is reworked over the course of Winnicott's career, not least of all, with the introduction of what we might call the usevalue of the object in the final development of his thought. Thus, further to the links that I have underlined in the two papers from the 1940s on war and primitive emotional development, Winnicott augments the theory of value in terms of the survival of the object. The essential point in the late work is that the object is valuable because and inasmuch as it survives being destroyed: "You have value for me because of your survival of my destruction of you" (1968, pp. 105-6). The destruction of an object that survives is a condition of its use and, therefore, of its value. In this case, violence creates the quality of externality that animates life, and so whether we think of violence as 'primary aggression' or 'destructiveness', it is only at the point of object survival that living feels real. Our survival depends on the way in which we use objects. Patients who can't make much use of anything bring with them a lot of making up to do. But where violence hasn't become dissociated and rendered redundant, it remains available for the creation of meaning that makes living together possible. To say the object survives means that it takes on a life of its own in the child's mind or, what amounts to the same thing, that the child survives its experience of omnipotence. We go on being who we are by surviving our ambitions.

\section{6}

Winnicott doesn't describe a trajectory from violence to ethics, but allows for the fact that violence is life, irrespective of what one thinks the good life ought to be. We need to keep the distinction between 'ethics' and 'morality' in mind here. In terms of the reaching impulse of primary aggression and the use-value of the object, survival strategies may be seen as ethical in a fundamental sense. But this isn't to say that physiology and the instinct of self-preservation settle matters, lest we reduce the whole discussion of war aims to the virtuous physiology of war (Luttwak, 1999). There is a further question to consider, then, concerning the wider sociological and political implications of Winnicott's thoughts on war. To put it schematically, the situation is primary and fundamental; the context, secondary and derivative. Thus the nursing environment comprises the fundamental situation (the original individual-environment set-up) alongside the various contexts of everyday life. The former consists of primary human values; the latter, more complex social orders of value. Furthermore, the more complex orders of value provide the vital order with psychosocial content as well as concrete forms of articulation and expression, starting with the family as the initial context in which the primary couple thrive. 
In my estimation, then, Winnicott allows for the distinction between ethics and morality. At the same time, he avoids the exaltation of the ethical over above the way of the world, firstly, by addressing the human predicament in terms of the inextricability of love and violence, and secondly, by connecting the earliest experiences of life to the "ever-widening circles of social life" (1963a, p. 91). War may be seen, therefore, as a particular context in which we find ourselves experiencing life. In assuming our responsibility for the enemy in this context, the shift from primary to secondary values, or from exposure to perception (object-perception), is inevitable. While our encounter with the enemy is rooted in a primordial sense of his vulnerability, which is immediately significant; nevertheless, physiology and human frailty don't cover the whole of one's perception of the enemy. Freud drew different conclusions from the same premise, namely, that "the initial helplessness [Hilfösigkeit] of human beings is the primal source of all moral motives" (1895, p. 318; emphasis in the original). Winnicott didn't share the deep suspicion of human motives that characterizes the Freudian interpretation. Instead, he reminds us that while history decides matters in human affairs, it does so against the background of a more primitive preoccupation with survival.

The dialectic of situation and context means that we invariably perceive the enemy, for whom we remain responsible at a basic existential level, in historical and political as well as ethical terms. This was certainly the case for Winnicott's generation and their perception of the Nazis: here was the enemy; here was someone you had to fight. It should be clear by now, however, that I don't believe the strategic argument ('we fight to exist') issues from a position of moral authority, and I don't believe Winnicott thought so either. But does it accord with the norms of moral conduct? Allowing for the primal sources of violence, the conduct of war sharpens the question concerning the circumstances under which the exercise of coercive authority and physical force by the state is considered legitimate. Violence becomes a sociological as well as an ethical question. On what grounds does one assume authority over the enemy?

Winnicott's views on war don't amount to anything like a coherent political theory, nor were they intended as such. Nevertheless, given the shift from the classical paradigm of modern war between sovereign states to the problematic of human rights under conditions of global capitalism, Winnicott's recourse to universal principles was prescient. The question of the enemy's humanity urges us to think through the proposition of 'war aims' on a number of levels. On what grounds do we retain a perception of adversaries as enemies rather than prey? To get the measure of this question, once again it is important to recognize the extent to which Winnicott's discussion moves between primary and secondary orders of value. The combination of ethics and strategy pertains at the primary and fundamental level of value; whereas psychosocial values, legal norms, and political reason are identified over against the tactical manoeuvre of fighting just to win.

Survival and survival strategies indicate something that feels worthwhile. We aim to live a life that is worth living. Evaluations, however, are not confined to the intrinsic value in living. Further to the existential basis of human value, the idea that there is more to survival than pugnacious combat, more than lex talionis or the law of talion, raises the issue not only of what we stand for, but also of whether or not our standing for this or that presupposes a moral argument. Winnicott maintained that we stand for something that is socially valuable in standing for 'democracy' and 'freedom'. Further to the intrinsic value in living, he counted these as moral goods, things that matter in a civilized life. As such, the freedom of the individual is seen as permanently valuable and something that must be defended. Under conditions of war and peace alike, 
the spontaneous violence of life gives rise to a mature evaluation in the face of barbarism and the world's cruelty.

Our perception of the enemy's humanity is based on exposure to his distress, which in turn affects our perception of the enemy as a political subject. I propose that the perception or recognition of one's enemy is the litmus test of higher or civilized values. And I think this claim stands on the grounds that the brutalization of the enemy exceeds the compulsion to survive and, as such, is a violation of life. In the case of war, brutality involves the extension of military conflict to "the art of murdering life" (Blunden, 1928, p. 161). Taken together, then, exposure to and perception of one's enemy - manifest at the level of primary and secondary values, respectively - constitute a particular encounter, in which the idea of 'military humanism' remains a contradiction in terms. It will help us grasp what is at stake, perhaps, if we consider the following description of Blunden's encounter with the enemy in Undertones of War: "Looking about in the now hazier October light, I saw some German prisoners drifting along, and I stopped them. One elderly gentleman had a jaw which seemed insecurely suspended; which I bound up with more will than skill, and obtained the deep reward of a look so fatherly and hopeful as seldom comes again" (1928, p. 92). Blunden may go in for ornamentation elsewhere (cf. a selection of war prose in Fall In, Ghosts), but not in this remarkable, and remarkably restrained, account. The prison appears as a 'gentleman' in whose gaze hope remains with the good father. To take another example, Blunden describes how "by the grace of God, suddenly two of the enemy from another direction wandered among them and surrendered. These prisoners duly arrived at battalion headquarters, seemingly half expecting to be eaten alive - a milkman and an elementary schoolmaster - most welcome guests" (1928, p. 102). The prose is equal to the situation, where, in the face to face encounter with one's enemy, one is immediately confronted with his stark and helpless state. Blunden brings out here, as in his poetry, the extent to which one is exposed to the enemy's state of exposure. The particular words and phrases he uses, rendering his encounter with the enemy as "gentlemen" and "welcome guests", recall the donation of goodness and, as such, confirm the ethical nature of the fundamental human situation.

The shift from primary and secondary values is not discontinuous in Blunden's description. Similarly, in Winnicott's discussion, the implicit shift from existential to moral and social values is maintained in and through the difficult task of 'reflection' itself. In effect, Winnicott uses the occasion of war to work through the question of value without reducing things to a series of oppositions. Most importantly, he provides us with a framework for a theory of life-values in which the coherent meaning of the ethical relation, on the one hand, is coupled with the different levels of evaluation operating in history and society, on the other. As I said in my introductory comments, I don't think Winnicott's reflections on war per se are particularly insightful. The important point is that psychoanalysis has a viable claim, in this case, as a critical resource of modern thought.

We are faced with the intrinsic value of living in the commandment "thou shalt not kill" (Exod. 20.13), which is instituted in human society at the level of laws and justice. Accordingly, the secondary level of value is subject to permanent negotiation, with modern options ranging (for instance) from the Hobbesian distinction between two types of social contract, pactum societatis and pactum subjectionis, to types of universal and cosmopolitan value in the Kantian tradition. It is important that we differentiate the encounter with the enemy, understood as an irreducible situation, from the historical and political activity of war, precisely, in order to evaluate the contingency of the latter from the exacting perspective of the former. How else might we make sense of our feelings of 
responsibility towards the enemy in the brutal and brutalizing context of warfare? No doubt contexts often get the better of us, we make mistakes, and hatred of the other person is a permanent menace. But whether or not Winnicott himself adhered consistently to the stringent evaluation of primary goodness; nevertheless, I think we can extrapolate from his argument the critical means for doing so in principle.

\section{7}

For Winnicott, fighting to exist isn't necessarily a violation of the humanity of one's enemy, nor is he ashamed to fight on these grounds. Why is there no shame or guilt in assuming this position, or acting in this way? Basically, because fighting to exist is not the same as fighting to kill. As long as violence is understood as a primary manifestation of life, the earliest relationship underpins the prohibition against killing as an ethical exigency. Freud (1930) counted the deep-seated "uneasiness" (Unbehagen) of civilization as a lesser evil, in a version of civilizational analysis pitted against European nationalism and its racial ideologies. In a so-called civilized life, where the instinctual imperative is regulated by means of the constraining illusions of morality and religion, discontent is considered inevitable. Accordingly, Freud assumed radical discontinuity in social as well as personal life. By contrast, Winnicott allowed for continuity in psychic life at the level of value: the shift from pre-ruth to ruth doesn't require the repression of our embodied, appetitive nature in the interests of culture and civilization. Most notably, the recourse to a "humanized conception" of the enemy rather than "talion" (1986, p. 66) reflects the continuity in ethical thought from ruthless love to concern.

The same holds for Hobbes as for Freud (1930) of course, for whom security and peace are maintained in the face of unregulated brutality and fear, understood as the natural condition of human life. There is an urgent need, in this case, to institute barriers to violence. But once again, for Winnicott we aren't up against ourselves in assuming responsibility for others. Winnicottian life-values stand in contrast to the Freudian critique of illusion. Goodness is seen as manifest to the extent that we understand what if feels like to express concern, and to respond with care, indeed, where we have had the experience of being looked after and loved ourselves. Far from an interminable drama of regulation and constraint, the good life is played out through the inextricability of love and violence. Accordingly, the normativity of the moral life is grounded in the very potentiality of human existence, where we are prepared for comprehension by the donation of goodness. The commandment "thou shalt not kill" elicits an immediate response rather than reasoned compliance. Justice thus proceeds from the intrinsic value in living, even as exposure to the humanity of one's enemy raises matters above the power to hurt and the brute fact of retaliation.

In shifting continuously between existential and socio-political evaluations, Winnicott weaves potentiality and morality together in various and complex ways. Most importantly, his reflections on war allow for a theory of value in which vulnerability and survival underwrite the ethical conditions of democracy, as distinct from a more formal set of rules or codes of conduct. In proposing that we stand for something that is valuable in standing for democracy, Winnicott's views about moral goods aren't necessarily inconsistent with his strategic argument as the sound basis for a discussion of war aims. The important point is that defending the idea of democracy as a moral good, is not the same as presenting the defence of democracy as a good reason for war. Of course 'democracy' has often been used in this way, for instance, as a key reference in the doctrine of 'just war'. Walzer (1992), the leading contemporary theorist of this doctrine, 
underwrites the legitimacy of war in moral terms and, thereby, provides a meta-legal justification of war.

An ethics of responsibility, however, doesn't necessarily entail the imposition of universal moral values on positive law in the manner of Walzer and others. In fact, Winnicott (1950, p. 242) remained resolutely opposed to the idea of a 'just war' in the name of democracy: "It would be possible to take a community and to impose on it the machinery that belongs to democracy, but this would not be to create a democracy". The imposition of democratic freedom, which amounts to the brutalization of the values of freedom and democracy, isn't something Winnicott tired to pass off as a positive good under the guise of a humanitarian argument. The principles of democracy and freedom, for which Winnicott believed the war was being fought, were not used to invest the war itself with a just meaning.

The fact that we cannot extrapolate a moral justification for war from Winnicott's theory of human nature, confirms the ethical substratum of his argument. He continued in the belief that war is fundamentally unjustifiable in conjunction with the exigency of survival as a condition of ethical life. The idea of British supremacy, or moral superiority over the enemy, cannot be maintained from the standpoint of the fundamental human situation. In fundamental terms one isn't fighting to make "the world safe for democracy" (Blunden, 1928, p. 5) so much as defending democracy itself as a resistant value. The capacity to resist comes to the fore in the context of war (Caygill, 2013), where the idea of democracy as a formal consensual arrangement of political life is less urgent than the affirmation of the democratic imagination as such. Thus, against the threat of barbarism and the brutalization of all values, Winnicott sought to defend democracy and freedom as life-values continuous with the intrinsic value in living.

There is something deeply provocative about Winnicott's reflections on war, where the experience of living itself is understood as a manifestation of freedom. It is my belief that the provocation came increasingly to the fore as Winnicott developed his ideas, most notably, under the heading of 'potentiality'. And the essential link between potentiality and creativity is confirmed in the final development of his work. The theory of value thus rests on a potential that yields the sense of the world: "Whatever definition [of creativity] we arrive at, it must include the idea that life is worth living or not, according to whether creativity is or is not a part of an individual person's living experience" (1970a, p. 39). In the context of war, one finds the necessary resources in oneself by responding spontaneously to the humanity of one's enemy, even where he succumbs to brutality. The response renders the provocation almost scandalous in making us responsible even for the brutality of the enemy. The ethics of warfare thus picks up the echo of an Orthodox liturgical phrase repeated in Dostoevsky's The Brothers Karamazov: "on behalf of all and for all” (1879-80, p. 164 et passim).

\section{8}

To recapitulate, the distinction between brutality and violence underpins Winnicott's reflections on war, understood as "a fight for life" (1940, p. 213). Standing for something that matters, in this case, is not seen as inimical to the manifestation of violence at the beginning of life. Winnicott doesn't advance an argument for the use of violence on moral grounds, but rather, counts us as no better than our enemies in our common fight to exist. As such, the discussion of war aims keys into the general theme of destructive aliveness in infancy and early childhood, where violence is identified as a 
source of human growth and development in "a natural sequence of ruthless love, aggressive attack, guilt feeling, sense of concern, sadness, desire to mend and build and give" (1964, p. 109). Winnicott's insistence on the inseparability of the human organism and its environment notwithstanding, the 'sequence' demonstrates his indebtedness to Klein regarding the thread of life.

Winnicott had more to say about war, however. Alongside the idea that we fight to exit as a spontaneous expression of life, he also sought "a possible further justification for fighting" (1940, p. 213) based on 'maturity' as a general evaluative principle. To be clear about my own view, I believe that primary and secondary values are essentially continuous; that the theory of life-values is coherent to the extent that the criterion of maturity, or any other principle of mental functioning, is continuous with the intrinsic value in living. And I take it that, for the most part, Winnicott provides grounds for this claim on the understanding that "basically in our natures we are like our enemies" (1940, p. 213). The idea that ethics is the deep meaning of social justice, that universal human rights presuppose a yet more fundamental encounter with the irreducible singularity of the other person, seems implicit to me in Winnicott's reflections on war.

The theory of life-values becomes inconsistent, however, if we privilege the psychosocial principle of maturity over the intrinsic value in living. Does Winnicott's theory of emotional development advantage the notion of 'maturity' in this way? More particularly, what does he make of the criterion of maturity in the context of war? Winnicott (1940, p. 213) claimed that we are actually better than our enemies insofar as "we aim at a more mature stage of emotional development than our enemies do". In the context of war, the criterion of maturity is used essentially to uphold the claim that we are better than our enemies. So long as it is understood as an expression of life, violence does not and cannot discriminate between human beings. Exposure to the humanity of one's enemy precedes the discriminatory logic of recognition and apprehension. In certain passages, however, Winnicott invokes 'maturity' rather than 'humanity' as the discriminatory principle in the context of war. He offers a justification of war on the grounds that "the Nazis are behaving like adolescents or pre-adolescents, whereas we are behaving like adults" (1940, p. 213).

Further to the revaluation of the values of goodness and survival, Winnicott argued that fighting itself may be a condition of our maturity, if not a way out of our immaturity. The psychosocial perspective doesn't account for our exposure to the enemy as welcome guests, but rather, renders the encounter itself as a maturational task: "On mutual respect between maturing men who have fought each other, a new period of peace could be reached, perhaps lasting another couple of decades, till a new generation grows up and again seeks to solve or obtain relief from its own problems in its own way" (1940, p. 220). The criterion of maturity thus points the discussion of war aims in the direction of original war. Psychologically speaking, Winnicott's stance affords genuine grounds for hope, but not for a final end to war. The optimism is burdened with the claim that nothing is gained or achieved without a fight and, moreover, that it is not for others to sacrifice themselves for our freedom.

There is no reason to believe that Winnicott revised these views in the light of subsequent historical events, views that certainly belie the image of a sentimental thinker. Predicated on the criterion of maturity, the argument Winnicott set out in 1940 makes an uncompromising case for war on psychological grounds, but also as a rite de passage. This isn't to suggest that one necessarily enjoys the fight. Winnicott's views aren't of apiece with the likes of Maurras, T. E. Hulme, and others on the matter of war. Nevertheless, the idea of war as unavoidable, coupled with the idea of individual freedom as permanently valuable, implies that military action may, under certain 
conditions, actually facilitate the maturational processes. Fighting to exit is seen as consistent not only with one's ethical responsibility to the enemy; but also with an appeal to the "good fury" that credits the soldier's maturity in battle (cf. Sassoon's 'The Kiss').

The criterion of maturity becomes a way of linking strategy with psychology rather than ethics: "If we think we stand more than our enemies do for maturity of development, we have a strong claim to the world's sympathy, but we do not thereby avoid having to fight, or being willing to die if need be" (1940, p. 219). The aim is first and foremost to win the war. Nor is sympathy a moral let alone an ethical claim, it is included here as a corollary to the proposition of military superiority and satisfaction: "We aim at reaching a saturation point when there is military satisfaction and mutual respect between combatants" (1940, p. 220). As a revaluation of the value of war from the perspective of necessary violence, Winnicott's argument remains essentially ambiguous. Nevertheless, it lends weight neither to those who object on grounds of conscience to military service, nor to those who, for reasons of personal or political gain, encourage us to war. By invoking the maturity of combatants rather than the humanity of the enemy, he saw war itself as a natural phenomenon, something immanent to the life of society. It would seem that the idea of a meagre peace, attendant upon the donation of goodness, isn't allowed the last word. Rather, the game becomes one of risk and chance, where peace presupposes war: "Allocation of war guilt has no part in this scheme, since all share it, for peace spells impotence except it be won through fighting and the personal risk of death" (1940, p. 220). The gods of war come hard on the heels of the peacemaker in this sentence.

In a tradition of political and social thought that extends from Clausewitz and Nietzsche to Weber and Foucault, the idea that war is inherent and pervasive in the social body remains prominent. The basic assumption is that conflict escalates as a matter of course, often with catastrophic consequences. Winnicott, an English liberal Tory of sorts, contributes to this line of thought with the idea that we enjoy freedom from war, just as we enjoy periods of stillness and quiet in general, only insofar as we have fought our way through to these states. And there is no guarantee of how long the peace may last. As we have seen, Winnicott identified the intrinsic quality of living with the violent nature of life, and although he adopted the psychosocial perspective of maturity on similar grounds, I don't believe that he held consistently to the ethical meaning of a mature response. Consequently, he came to think of peace in terms of the defeat of some and the victory of others. Here, where the humanity of the other person falls foul of the allure of universalism, there is no peace that comes about without a real fight or the elevation of principles and future universals over against Sassoon's "intolerably nameless names" (cf. 'On Passing the New Menin Gate').

Finally, unlike either conscientious objectors or warmongers, Winnicott proposed that "[w]e are trying to feel free as well as to be free, and to be willing to fight without being pugnacious, to be potential fighters interested in the arts of peace" (1940, p. 214). By the 'arts of peace' he meant all those activities that comprise the 'social provision', activities through which maturity enters into the calculations of the state. As he saw it, the underlying aim of security involves making "a personal advance to maturity" and, furthermore, he claimed that it is only insofar as elements of the enemy are "mature" that we can "usefully give them the idea of freedom" (1940, p. 219). From the psychosocial perspective, war is understood as a way out of our immaturity, in the aftermath of which we are faced with the task first of re-establishing our democratic way of life amongst ourselves, and secondly, of welcoming "the mature elements in the enemy countries" (1940, p. 219). Again, further to the reparation of social bonds on the 
home front, the post-war task involves identifying sympathetic tendencies within the enemy population rather than imposing democratic values from the outside. This is anything but a straightforward task, and clearly the problem hasn't become any less urgent today. Similar arguments have been expressed in the context of the Islamic revival, and the so-called 'war on terror', since the end of the twentieth-century. The 'difficult task' becomes a 'permanent task', where the articulation of difficulty and permanence is predicated on "the emotional development of society" (1950, p. 241).Winnicott thus identified an essential problem of our time regarding the maintenance of peace as maturity. 


\section{Reference}

Abram, J. (2013) 'The evolution of Winnicott's theoretical matrix: A brief outline', in J. Abram (ed.) Donald Winnicott Today, London and New York: Routledge, pp. 73-112.

Blunden, E. (1928) Undertones of War, London: Penguin Books, 2010.

Blunden, E. (2014) Fall In, Ghosts: Selected War Prose, edited with an introduction by Robyn Marsack, Manchester: Carcanet.

Caygill, H. (2013) On Resistance: A Philosophy of Defiance, London: Bloomsbury.

Dostoevsky, F. (1879-80) The Brothers Karamazov, London: Everyman's Library, 1997.

Enright, A. (2015) The Green Road, London: Jonathan Cape.

Freud, S. (1895) Project for a Scientific Psychology. Standard Edition, vol. 1: 281-397.

Freud, S. (1915) 'Thoughts for the times on war and death', Standard Edition, vol. 14: 273-302.

Freud, S. (1920) Beyond the Pleasure Principle. Standard Edition, vol. 18: 1-64.

Freud, S. (1926 [1925]) Inhibitions, Symptoms and Anxiety. Standard Edition, vol. 20: 75-175.

Freud, S. (1930) Civilization and Its Discontents. Standard Edition, vol. 21: 57-145.

Freud, S. (1933 [1932]) New Introductory Lectures on Psycho-Analysis. Standard Edition, vol. 22: 1-182.

Freud, S. (1933) 'Why war?’ Standard Edition, vol. 22: 197-215.

Genet, J. (1977) 'Violence and brutality', in J. Fort (ed.) The Declared Enemy: Texts and Interviews, California: Stanford University Press, 2004, pp. 171-77.

Graves, R. (1929) Good-bye to All That, London: Penguin Books, 2000.

Klein, M. (1932) The Psycho-Analysis of Children, London: Hogarth Press, 1980.

Luttwak, E. N. (1999) 'Give war a chance’, Foreign Affairs, 78(4): 36-44.

Oliner, M. (2012) Psychic Reality in Context: Perspectives on Psychoanalysis, Personal History, and Trauma, London: Karnac.

Robinson, M. (2014) Lila, London: Virago Press.

Rodman, F. R. (1987) The Spontaneous Gesture: Selected Letters of D. W. Winnicott, Cambridge, Massachusetts: Harvard University Press. 
Ricoeur, P. (1970) Freud and Philosophy: An Essay on Interpretation, New Haven and London: Yale University Press.

Sassoon, S. (1983) The War Poems, R. Hart-Davis (ed.), London: Faber and Faber.

Scarfone, D. (2013) 'From traces to signs: presenting and representing', in Unrepresented States and the Construction of Meaning: Clinical and Theoretical Contributions, London: Karnac Books, pp. 75-94.

Segal, H. (1977) Psychoanalysis, Literature and War: Papers 1972-1995, London and New York: Routledge.

Tóibín, C. (2012) The Testament of Mary, London: Penguin Books.

Walzer, M. (1992) Just and Unjust Wars, New York: Basic Books.

Winnicott, D. W. (1940) 'Discussion of war aims', in C. Winnicott, R. Shepherd and M. Davis (eds.) Home Is Where We Start From, Harmondsworth: Penguin Books, 1986, pp. 210-20.

Winnicott, D. W. (1941) 'The observation of infants in a set situation', in Through Paediatrics to Psychoanalysis, London: Hogarth Press, 1978, pp. 52-69.

Winnicott, D. W. (1945) 'Primitive emotional development', in Through Paediatrics to Psychoanalysis, London: Hogarth Press, 1978, pp. 145-56.

Winnicott, D. W. (1950) 'Some thoughts on the meaning of the word "democracy", in C. Winnicott, R. Shepherd and M. Davis (eds) Home Is Where We Start From, Harmondsworth, Penguin Books, 1986, pp. 239-59.

Winnicott, D. W. (1956) 'The anti-social tendency', in C. Winnicott, R. Shepherd and M. Davis (eds) Deprivation and Delinquency, London: Tavistock Publications, pp. 12031.

Winnicott, D. W. (1960) 'What irks?' in C. Winnicott, C. Bollas, M. Davis and R. Shepherd (eds.) Talking to Parents, Reading, MA: Addison-Wesley, 1993, pp. 65-86.

Winnicott, D. W. (1963a) 'From dependence towards independence in the development of the individual', in The Maturational Processes and the Facilitating Environment: Studies in the Theory of Emotional Development, London: Hogarth Press, 1985, pp. 8392.

Winnicott, D. W. (1963b) 'Morals and education', in The Maturational Processes and the Facilitating Environment: Studies in the Theory of Emotional Development, London: Hogarth Press, 1985, pp. 93-105.

Winnicott, D. W. (1964) The Child, the Family, and the Outside World, Harmondsworth: Penguin Books, 1957 
Winnicott, D. W. (1968) 'The use of an object and relating through identifications', in Playing and Reality, Harmondsworth: Penguin Books, 1985, pp. 101-111.

Winnicott, D. W. (1970a) 'Living creatively', in C. Winnicott, R. Shepherd and M. Davis (eds) Home Is Where We Start From, Harmondsworth, Penguin Books, 1986, pp. 39-54.

Winnicott, D. W. (1970b) 'Residential care as therapy', in C. Winnicott, R. Shepherd and M. Davis (eds.) Deprivation and Delinquency, London: Tavistock Publications, 1984, pp. 220-28.

Winnicott, D. W. (1971) 'The place where we live', in Playing and Reality, Harmondsowth: Penguin Books, 1985, pp. 122-129.

Winnicott, D. W. (1986) Holding and Interpretation: Fragment of an Analysis, London: Hogarth Press.

Winnicott, D. W. (1988) Human Nature, London: Free Association Books. 